\title{
Comparative cytogenetic analysis of some species of the Dendropsophus microcephalus group (Anura, Hylidae) in the light of phylogenetic inferences
}

Lilian Ricco Medeiros ${ }^{1 \dagger}$, Luciana Bolsoni Lourenço ${ }^{1 *}{ }^{*}$, Denise Cerqueira Rossa-Feres ${ }^{2}$, Albertina Pimentel Lima ${ }^{3}$, Gilda Vasconcellos Andrade ${ }^{4}$, Ariovaldo Antonio Giaretta ${ }^{5}$, Gabriel Toselli Barbosa Tabosa Egito ${ }^{1,6}$ and Shirlei Maria Recco-Pimentel ${ }^{1}$

\begin{abstract}
Background: Dendropsophus is a monophyletic anuran genus with a diploid number of 30 chromosomes as an important synapomorphy. However, the internal phylogenetic relationships of this genus are poorly understood. Interestingly, an intriguing interspecific variation in the telocentric chromosome number has been useful in species identification. To address certain uncertainties related to one of the species groups of Dendropsophus, the D. microcephalus group, we carried out a cytogenetic analysis combined with phylogenetic inferences based on mitochondrial sequences, which aimed to aid in the analysis of chromosomal characters. Populations of Dendropsophus nanus, Dendropsophus walfordi, Dendropsophus sanborni, Dendropsophus jimi and Dendropsophus elianeae, ranging from the extreme south to the north of Brazil, were cytogenetically compared. A mitochondrial region of the ribosomal $12 S$ gene from these populations, as well as from 30 other species of Dendropsophus, was used for the phylogenetic inferences. Phylogenetic relationships were inferred using maximum parsimony and Bayesian analyses.

Results: The species $D$. nanus and D. walfordi exhibited identical karyotypes $(2 n=30 ; F N=52)$, with four pairs of telocentric chromosomes and a NOR located on metacentric chromosome pair 13. In all of the phylogenetic hypotheses, the paraphyly of D. nanus and D. walfordi was inferred. D. sanborni from Botucatu-SP and Torres-RS showed the same karyotype as $D$. jimi, with 5 pairs of telocentric chromosomes $(2 n=30 ; F N=50)$ and a terminal NOR in the long arm of the telocentric chromosome pair 12. Despite their karyotypic similarity, these species were not found to compose a monophyletic group. Finally, the phylogenetic and cytogenetic analyses did not cluster the specimens of $D$. elianeae according to their geographical occurrence or recognized morphotypes.

Conclusions: We suggest that a taxonomic revision of the taxa D. nanus and D. walfordi is quite necessary. We also observe that the number of telocentric chromosomes is useful to distinguish among valid species in some cases, although it is unchanged in species that are not necessarily closely related phylogenetically. Therefore, inferences based on this chromosomal character must be made with caution; a proper evolutionary analysis of the karyotypic variation in Dendropsophus depends on further characterization of the telocentric chromosomes found in this group.
\end{abstract}

Keywords: Chromosome, Phylogeny, Dendropsophus, Anura

\footnotetext{
*Correspondence: bolsoni@unicamp.br

${ }^{\dagger}$ Equal contributors

'Departamento de Biologia Estrutural e Funcional, Instituto de Biologia, Universidade Estadual de Campinas (UNICAMP), 13086-863, Campinas, SP, Brazil

Full list of author information is available at the end of the article
}

\section{Biomed Central}

(C) 2013 Medeiros et al.; licensee BioMed Central Ltd. This is an Open Access article distributed under the terms of the Creative Commons Attribution License (http://creativecommons.org/licenses/by/2.0), which permits unrestricted use, distribution, and reproduction in any medium, provided the original work is properly cited. 


\section{Background}

The genus Dendropsophus was resurrected by Faivovich et al. [1] to include all of the species previously referred to as the 30-chromosome Hyla species. However, fewer than 30 of the 92 species of Dendropsophus currently known [2] have been karyotyped to date [3-11]. Because the karyotype of Xenohyla, which is thought to be the sister group of Dendropsophus, is still unknown, it is not possible to infer whether $2 \mathrm{n}=30$ is a synapomorphy of Dendropsophus or Dendropsophus + Xenohyla [1].

The monophyly of Dendropsophus has been supported by molecular data in different studies $[1,12,13]$. Nevertheless, the monophyly of each of the nine species groups recognized in Dendropsophus by Faivovich et al. [1] remains an interesting issue for further research.

The D. microcephalus group is the most speciose group in the genus, including more than 30 species [1,2]. Wiens et al. [12] expanded the number of sampled species of the D. microcephalus group and reported the paraphyly of this group with respect to Dendropsophus riveroi, which had been allocated to the $D$. minimus group by Duellman [14] and tentatively kept there by Faivovich et al. [1]. Fouquet et al. [15] recovered within the D. microcephalus group not only $D$. riveroi but also D. gaucheri, a species previously allocated to the $D$. parviceps group. Despite that the interspecific relationships in the $D$. microcephalus group remain to be elucidated, some of its species were putatively attributed to two clades by Faivovich et al. [1]: the Dendropsophus decipiens clade (including D. berthalutzae, D. decipiens, D. haddadi and D. oliveirai) and the Dendropsophus rubicundulus clade (including D. anataliasiasi, D. araguaya, D. cachimbo, D. cerradensis, D. elianeae, D. jimi, $D$. rhea, D. rubicundulus and D. tritaeniatus). These clades correspond to species groups previously proposed by other researchers [16-18], but Faivovich et al. [1] emphasized the absence of a rigorous test for the monophyly of each of these groups.

In addition to the lack of phylogenetic information about the species of the D. microcephalus group, several taxonomic questions have persisted. The very small size and highly similar external morphologies of these frogs make their taxonomic identification challenging, resulting in a number of taxonomic problems, including specimen misidentification. For example, the species $D$. nanus, $D$. sanborni, D. walfordi and D. jimi have been the target of taxonomic discussion [10,15,19]. Dendropsophus sanborni was already considered to be a subspecies of $D$. nanus $[20,21]$ but was later considered a valid species by Basso et al. [22]. Furthermore, based on morphological data, Lutz [23] and Duellman [24] considered D. walfordi to be synonymous with D. nanus, but Langone and Basso [19] resurrected $D$. walfordi as a valid species based on vocalization data and tadpole morphology. Recently, Fouquet et al. [15], in a phylogenetic analysis that included two specimens of $D$. nanus and one of $D$ walfordi, again raised questions regarding these taxa. However, the authors could not draw any conclusions because of the low number of populations sampled and strongly recommended further studies to evaluate the status of $D$. nanus and $D$. walfordi.

Interestingly, the karyotypes found for $D$. nanus and $D$. sanborni specimens by Medeiros et al. [10] were the same as those described previously for D. sanborni [8] and $D$. nanus [6], respectively. Medeiros et al. [10] argued that the morphological similarity of these two species had resulted in their misidentification, which was corroborated by Gruber et al. [11], who detected the same karyotypes described by Medeiros et al. [10] for D. nanus and D. sanborni. The karyotypes of $D$. walfordi and $D$. jimi remain unknown.

Dendropsophus elianeae is another member of the $D$. microcephalus group with intriguing characteristics that warrant further study. This species was recently described by Napoli and Caramaschi [25] after a revision of specimens previously identified as $D$. rubicundulus. Three additional geographical morphotypes were recognized by Napoli and Caramaschi [25]: one for specimens from the southern regions of the Brazilian states of São Paulo and Minas Gerais, a second for specimens from the northern localities of the Brazilian state of São Paulo and a third morphotype for the specimens from central Brazil. Cytogenetic analyses had previously been performed only with specimens of D. elianeae from a locality in the southern region of São Paulo state, and some karyotypic differences between this species and D. rubicundulus were described [11]. Cytogenetic and molecular analyses including all three morphotypes described by Napoli and Caramaschi [25] are not yet available.

Considering the interesting variations in the number and size of telocentric chromosomes and the variation in NOR location among the karyotypes of the Dendropsophus species [examples in 4,6,10,11]; review in [26], we contributed to the study of the $D$. microcephalus group by (i) describing the karyotypes of $D$. walfordi and $D$. jimi and (ii) providing karyotypic data for several of the populations of $D$. nanus, $D$. sanborni and D. elianeae that were not included in the studies by Skuk and Langone [8], Medeiros el al. [10] or Gruber et al. [11]. Additionally, 12S rDNA sequences from all of these species were included in a phylogenetic analysis aiming to better understand the relationships among the species that were analyzed cytogenetically. Because of the taxonomic questions regarding the $D$. microcephalus group, we used the same specimens to obtain DNA sequences and cytogenetic data whenever possible. Through this approach, we also intended to show how analyzing chromosomal characters based on the phylogenetic relationships inferred from another set of data could be helpful in investigating which chromosomal characters constitute synapomorphies, symplesiomorphies and homoplasies. This type of combined analysis could be particularly 
important when the chromosomal data available are not sufficient for a proper phylogenetic analysis.

\section{Results \\ Phylogenetic analyses}

In all of the inferred topologies (Figure 1 and Additional files 1 and 2: Figures S1 and S2), the species currently assigned to the $D$. microcephalus group included in this study clustered within a clade that also included the species $D$. riveroi. The phylogenetic relationships inferred for $D$. jimi, a species belonging to the $D$. microcephalus group that was not included in the previous phylogenetic analyses of Faivovich et al. [1], Wiens et al. [12] and Pyron and Wiens [13], differed among the analyses. In the topology inferred through POY analysis, D. jimi was the sister group of a clade comprising $D$. rubicundulus (see discussion about the $D$. rubicundulus sequence used below), $D$. elianeae, D. sanborni, D. anataliasiasi, Dendropsophus aff. cruzi and D. minusculus (Figure 1). However, in the TNT analysis, $D$. jimi and D. bipunctatus formed a sister group to the $D$. minusculus $+D$. berthalutzae group (Additional file 1: Figure S1). In the Bayesian analysis, D. jimi was included in a polytomy with $D$. berthalutzae, $D$. bipunctatus and $D$. minusculus (Additional file 2: Figure S2).

Dendropsophus anataliasiasi, another species not included in the previous studies of phylogenetic relationships, was grouped with D. sanborni in the TNT and POY cladograms, but the clade did not receive significant support (Figure 1 and Additional file 1: Figure S1). In the Bayesian analysis, $D$. anataliasiasi was included in a polytomy with D. sanborni and D. elianeae (Additional file 2: Figure S2).

Interestingly, the sequence assigned to $D$. rubicundulus by Faivovich et al. [1] [GenBank: AY843661] clustered among the $D$. elianeae sequences in all of the analyses (Figure 1 and Additional files 1 and 2: Figures S1 and S2). In addition, the specimens of $D$. elianeae were not grouped according to their geographic distribution, despite the fact that several specimens representing the geographic range of this species (central Brazil, Minas Gerais state and different regions of São Paulo state) were analyzed.

Another relevant finding was the paraphyly of $D$. nanus and $D$. walfordi, which was inferred in all the analyses (Figure 1 and Additional files 1 and 2: Figures S1 and S2). Interestingly, the karyotype described for $D$. walfordi was completely indistinguishable from that described for $D$. nanus, as reported below.

\section{Chromosomal analysis}

Dendropsophus elianeae, D. jimi, D. nanus, D. sanborni and $D$. walfordi exhibited karyotypes with $2 \mathrm{n}=30$ chromosomes (Figures 2, 3, 4 and 5) but differed in the number of telocentric chromosomes. As a proper inference of the homeology of the chromosomes belonging to the different species is not yet possible, we ordered them within each karyotype according to their sizes.

The specimens of $D$. nanus and $D$. walfordi showed very similar karyotypes, with a fundamental number (NF) of 52 , 6 pairs of metacentric chromosomes (pairs 3, 8, 9, 10, 11 and 13), 5 pairs of submetacentric chromosomes (pairs 1 , 2, 4, 5 and 7) and 4 pairs of telocentric chromosomes (pairs 6, 12, 14 and 15) (Figure 2). One specimen of D. nanus from Serra da Bodoquena (ZUEC 13179) presented a karyotype with a heteromorphic pair 6 , which was composed of a telocentric morph $6 \mathrm{a}$ and a submetacentric morph 6b; its NF was, therefore, 53 (Figures 2A, 2B and Additional file 3: Figure S3). In some $D$. nanus and $D$. walfordi metaphases, a secondary constriction was detected distally on the long arm of pair 13 (Figures 2A and $2 \mathrm{C}$ ) in the same site detected as a NOR by Ag-NOR staining (Figures $2 \mathrm{~A}$ and $2 \mathrm{C}$ - insets) and by FISH with an rDNA probe (Figures $4 \mathrm{~A}$ and $4 \mathrm{~B}$ ). The $\mathrm{C}$-banding analysis detected the centromeric regions of all of the chromosomes of D. nanus and D. walfordi (Figures $2 \mathrm{~B}$ and 2D). In the C-banded metaphases of specimens of $D$. nanus from Telêmaco Borba, a small pericentromeric C-band was detected in the metacentric chromosome 3 (Figure 2B).

The karyotype of $D$. sanborni was very similar to that of D. jimi, with $\mathrm{NF}=50,6$ pairs of metacentric chromosomes (pairs 3, 8, 9, 10, 11 and 14), 4 pairs of submetacentric chromosomes (pairs 1, 2, 4 and 7) and 5 pairs of telocentric chromosomes (pairs 5, 6, 12, 13 and 15) (Figure 3). In $D$. sanborni, interindividual variation was observed in relation to NOR sites. Although specimens from Torres-RS provided a NOR that was detected terminally in the long arm of chromosome 12 (pair 12" in Figures 3A and 4E), specimens from Botucatu-SP presented a NOR that was detected interstitially in the long arm of chromosome 12 (pair 12 in Figures 3A and 4C). Interestingly, one specimen from Botucatu-SP exhibited a heteromorphic chromosome pair 12 (designated pair 12') that was composed of a chromosome with an interstitial NOR and a chromosome with an interstitial and a terminal NOR (Figures 3A- inset and 4D). In D. jimi, both Ag-NOR staining and FISH with the rDNA probe detected a NOR in the terminal region of the long arm of chromosome 12 (Figures $3 \mathrm{C}$ and $4 \mathrm{~F}$ ). Cbanding analysis detected the centromeric regions of all of the chromosomes in the D. jimi and D. sanborni karyotypes (Figures 3B and 3D).

All of the specimens of D. elianeae had a karyotype with $\mathrm{FN}=56$ composed of 8 pairs of metacentric chromosomes (pair 3, 8-12, 14-15), 4 pairs of submetacentric chromosomes (pairs 1, 2, 4 and 7), 1 pair of subtelocentric chromosomes (pair 13) and 2 pairs of telocentric chromosomes (pairs 5 and 6) (Figure 5). The NOR was detected in the short arm of the subtelocentric chromosome 13 by Ag-NOR staining (Figures 5A - inset and 5C). This NOR could be seen as a secondary constriction in only 


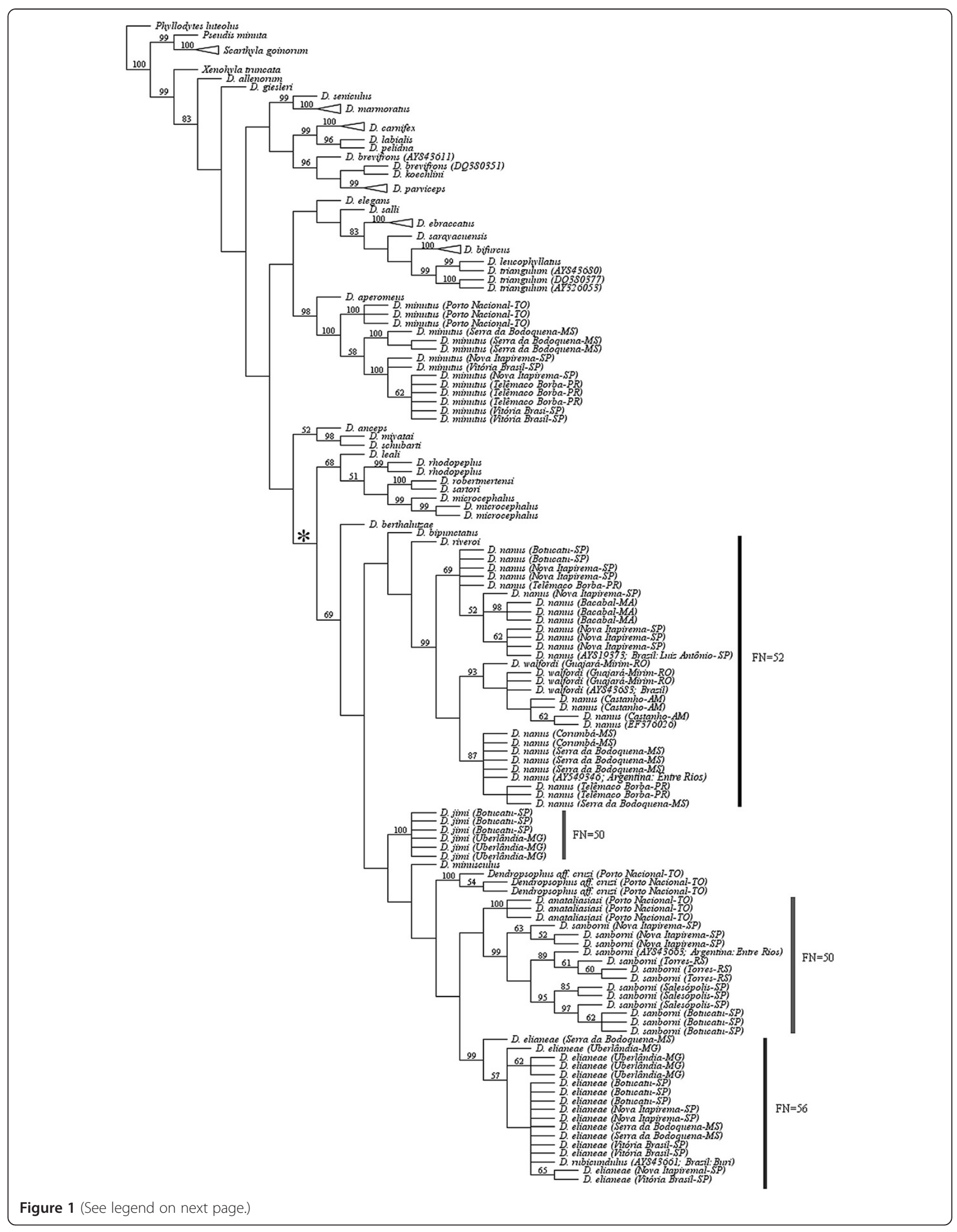


(See figure on previous page.)

Figure 1 Strict consensus cladogram scored at 2070 inferred from POY analyses of 12S rDNA sequences. Numbers adjacent to nodes indicate bootstrap values. The karyotype fundamental number (FN) is indicated for some species. The asterisk indicates the node of the clade that includes the species of the D. microcephalus group. Sample locations are provided for all the specimens we collected for this study and also for the specimens of D. nanus, D. sanborni, D. rubicundulus and D. walfordi whose 12S rDNA sequences were already available at the GenBank (their GenBank accession numbers are indicated). The GenBank accession numbers are also indicated for D. brevifrons and D. triangulum because these species were not recovered as monophyletic groups.

14 chromosomes of 10 Giemsa-stained metaphases (Figures $5 \mathrm{~A}$ and $5 \mathrm{C}$ ) and these samples were used for the inference of the arm ratio of chromosome 13. All eight measured Giemsa-stained metaphases were subjected to analysis using the Ag-NOR method to confirm the NOR location. Because the average value for the arm ratio was 3.32 , the NOR-bearing chromosome 13 was classified as subtelocentric, following the convention of Green and Sessions [27]. In the majority of the Giemsa-stained metaphases in which the NOR constriction could not be observed, the limit of the short arm of chromosome 13 could not be identified; as such, it could have been misinterpreted as telocentric. In these cases, sequential staining using Giemsa and the Ag-NOR method was especially useful for the correct recognition of the NORbearing chromosome pair. The C-banding analysis detected all of the centromeric regions in the karyotype of this species (Figure 5B).

\section{Discussion}

Our phylogenetic analyses increased the number of sampled species of the D. microcephalus group from 11 [the number of species analyzed by Wiens et al. [12], not including $D$. rubicundulus because of the taxonomic questions regarding sequence AY843661 mentioned below] to 15 due to the inclusion of $D$. anataliasiasi, D. cruzi, $D$. elianeae and D. jimi. All of the sampled species from this group clustered in a clade that also included $D$. riveroi, a species that was previously assigned tentatively to the $D$. minimus group $[1,14]$ but has a known phylogenetic relationship with the species of the D. microcephalus group, as indicated by Wiens et al. [12] and Fouquet et al. [15]. Despite the congruence of these data, inference based on a larger number of Dendropsophus species is still necessary to conclusively assess the monophyly of the D. microcephalus group. The inclusion of a number of species currently assigned to the D. microcephalus group, which comprises more than 30 species, is particularly important not only for testing the monophyly of this group but also for proper inferring the internal relationships.

With regard to the $D$. rubicundulus clade, as tentatively defined by Faivovich et al. [1], our sample also left questions. In our analyses, the sampled species of this group did not compose a clade. In the POY analysis, the lessinclusive clade that clustered the three sampled species of the $D$. rubicundulus group (D. anataliasiasi, D. elianeae and D. jimi) also included D. sanborni, D. minusculus and Dendropsophus aff. cruzi. In the TNT and Bayesian inferences, the $D$. rubicundulus group was additionally paraphyletic with respect to $D$. bipunctatus and $D$. bertalutzae, the latter being the only species of the $D$. decipiens group [1] sampled here. Therefore, the monophylies of the $D$. rubicundulus group and the $D$. decipiens group remain to be tested.

Because the internal relationships of the D. microcephalus group are still unclear, it is not yet possible to present an accurate evolutionary interpretation of all of the cytogenetic data available for the Dendropsophus species, including the variation of the karyotypic fundamental number. However, some clades were stable and highly supported in all of our inferences and allowed an interesting combined phylogenetic and cytogenetic analysis that provided relevant contributions on the species level. One of these concerns the species D. nanus and D. sanborni, which were subject of taxonomic controversy until recently. The $12 \mathrm{~S}$ rDNA sequences we obtained for D. nanus were very similar to those assigned to this species by Faivovich et al. [1] [GenBank: AY549346] and Wiens et al. [28] [GenBank: AY819373]; these sequences were clustered together in our phylogenetic analyses within a clade that did not include $D$. sanborni. The same populations of D. nanus and D. sanborni sampled for our phylogenetic analyses were also karyotyped here, as well as by Medeiros et al. [10], and showed $2 \mathrm{n}=30$ karyotypes with $\mathrm{FN}=52$ or 50 , respectively. Our combined analyses corroborate the hypothesis proposed by Medeiros et al. [10] and supported by Gruber et al. [11] regarding the identification of the species analyzed. However, they disagree with the identification presented by Skuk and Langone [8]. This finding highlights how important it is to generate and analyze a different set of data obtained from the same populations or specimens. Therefore, combining other sets of data, in addition to their cytogenetic characters, seems to be an interesting approach that should be considered by cytogeneticists, particularly when studying not only species with known taxonomic questions but also polymorphic species.

All of the specimens of $D$. nanus that were analyzed cytogenetically here (from Telêmaco Borba-PR, BacabalMA and Serra da Bodoquena-MS) showed the same karyotype previously described by Medeiros et al. [10] (for specimens of D. nanus from Nova Itapirema-SP) and Gruber et al. [11] (for specimens of D. nanus from Rio Claro-SP), 


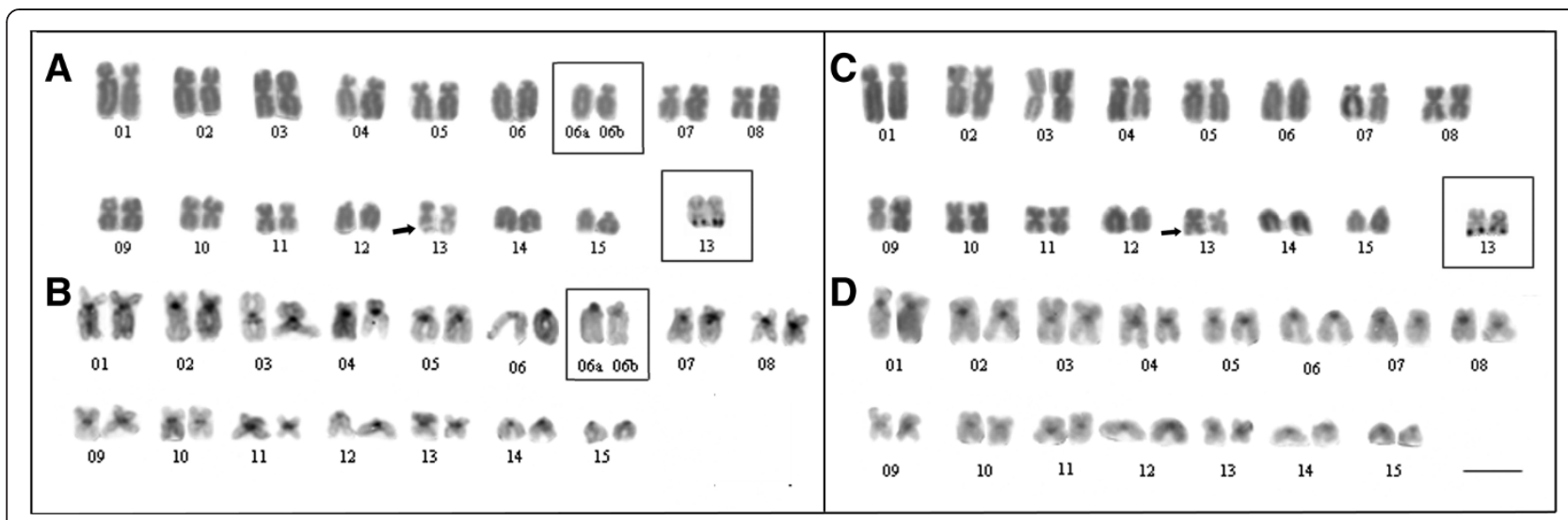

Figure 2 Karyological data of Dendropsophus nanus and Dendropsophus walfordi. Karyotype arranged from Giemsa-stained (A, C) and C-banded metaphases (B, D) of D. nanus (A, B) and D. walfordi (C, D). The insets in $\mathbf{A}$ and $\mathbf{C}$ show the heteromorphic pair 6 of the ZUEC 13179 specimen and the Ag-stained NOR-bearing chromosomes 13. In $\mathbf{B}$, note a C-band adjacent to the centromere of chromosome 3 observed in individuals from Telêmaco Borba-PR. The arrows in $\mathbf{A}$ and $\mathbf{C}$ indicate the secondary constrictions of the NORs. Bar $=5 \mu \mathrm{m}$.

with the exception of one specimen from Serra da Bodoquena, which had $\mathrm{FN}=53$ instead of $\mathrm{FN}=52$. The heteromorphism observed for pair 6 in this specimen of $D$. nanus, in which chromosome 6 a was morphologically similar to the telocentric pair 6 of the other specimens whereas chromosome $6 \mathrm{~b}$ was submetacentric, might be explained by pericentric inversion. The hypothesis of inversion is based on the chromosomal morphology and consistent total length of the submetacentric chromosome, which would have been altered in the case of a chromosomal deletion or translocation. Another feature found in only a few specimens of $D$. nanus is a heterochromatin block observed close to the centromere in the long arm of chromosome 3 that occurs in some specimens from Telêmaco Borba.

The typical karyotype of $D$. nanus, with $F N=52$, differs greatly from that of $D$. sanborni, which has five pairs of telocentric chromosomes $(\mathrm{FN}=50)$. The karyotype of the specimens of $D$. sanborni from Torres-RS described here is identical to that previously presented for specimens from Nova Itapirema-SP [10], even with regard to the terminal location of the NOR in the telocentric chromosome 12. Karyotyping of specimens of D. sanborni from BotucatuSP revealed an intrapopulational variation because three morphs of the NOR-bearing chromosome 12 were found. One of these morphs exhibiting an interstitial NOR was the same type found in the specimens of $D$. sanborni from Rio Claro-SP analyzed by Gruber et al. [11].

Interestingly, the karyotype of $D$. jimi, which was described here for the first time, is identical to that of specimens of D. sanborni from Nova Itapirema-SP [10], TorresRS and Botucatu-SP (only those with a terminal NOR in chromosome pair 12). Based on the phylogenetic

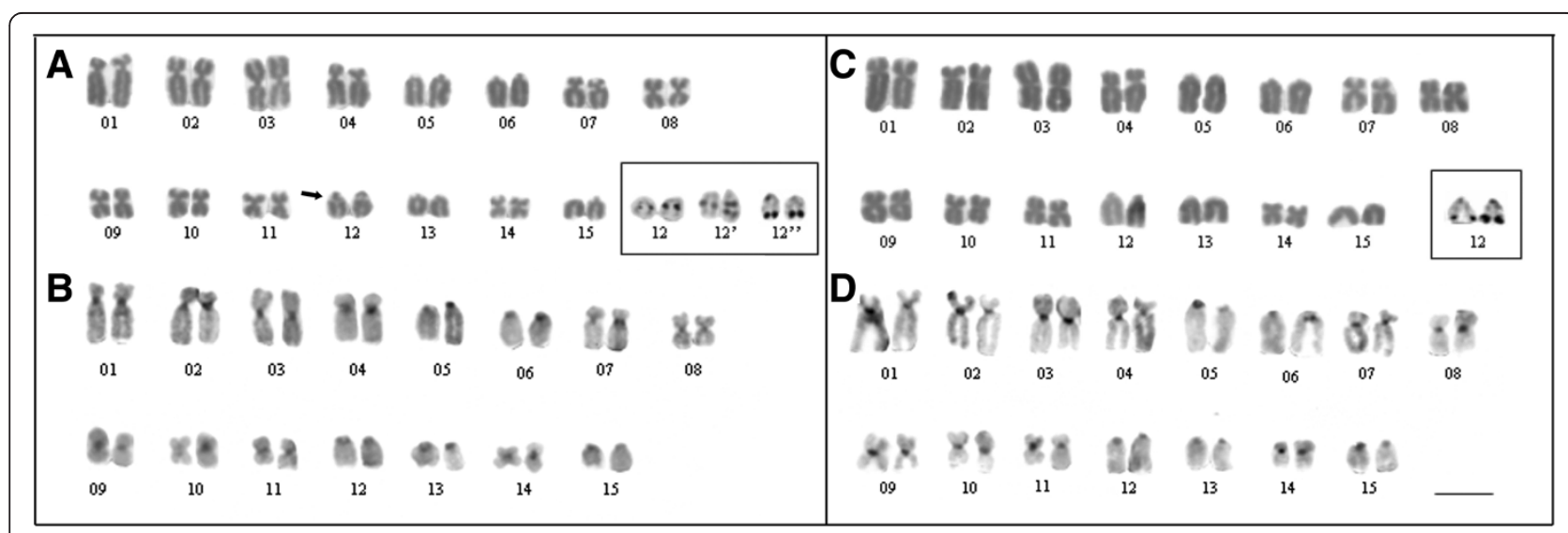

Figure 3 Karyological data of Dendropsophus sanborni and Dendropsophus jimi. Karyotype arranged from Giemsa-stained (A, C) and C-banded metaphases (B, D) of D. sanborni (A, B) and D. jimi (C, D). The insets in $\mathbf{A}$ and $\mathbf{C}$ show the Ag-stained NOR-bearing chromosomes. The inset in A shows the NOR-bearing chromosome pairs 12 and 12', found in Botucatu-SP, and the pair 12", found in Torres- RS. The arrow indicates the secondary constriction in the NOR-bearing chromosome pair 12 of D. sanborni. Bar $=5 \mu \mathrm{m}$. 
relationships of $D$. jimi and $D$. sanborni inferred here, the karyological similarities between these taxa cannot be interpreted as synapomorphies of these species. This finding is a clear example of the importance of interpreting chromosomal data in light of their phylogenetic inferences. If this caution had not been taken and only the similarities between the karyotypes of these anurans had been reported, it could lead to misinterpretation by non-specialist readers, and the cytogenetic similarities could be inadequately read as synapomorphies for the species in study.

Another relevant contribution of our analyses concerns the paraphyly of $D$. nanus with respect to $D$. walfordi. The nesting of $D$. walfordi (from Brazil) among three specimens of D. nanus (two from French Guiana and one from Argentina) was already recovered by Fouquet et al. [15,29].
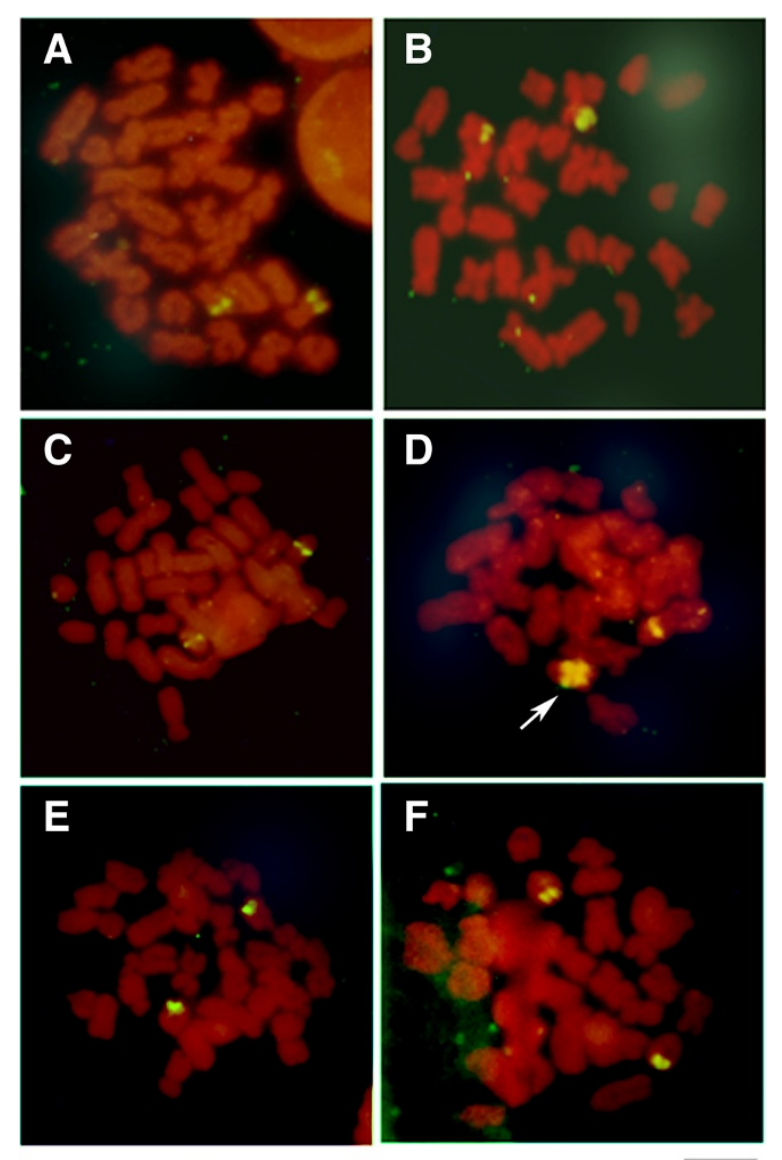

Figure 4 Chromosome mapping of nucleolar rDNA in Dendropsophus nanus, Dendropsophus walfordi, Dendropsophus sanborni and Dendropsophus jimi. Metaphases of D. nanus (A), D. walfordi (B), D. sanborni from Botucatu-SP (C, D) and Torres-RS (E), and D. jimi (F) after FISH with rDNA probes. In C-E, note the three different NOR phenotypes found for D. sanborni, which are identified by the presence of the NOR-bearing chromosome pairs 12 (C), 12' (D) and 12"' (E) (see text for details). The arrow in $\mathbf{D}$ indicates the duplicated NOR in one of the homologs of the NORbearing chromosome pair $12^{\prime}$. Bar $=5 \mu \mathrm{m}$.
In our study, which included specimens from seven Brazilian localities, the paraphyly of $D$. nanus and $D$. walfordi was also inferred. Interestingly, the karyotype of $D$. walfordi was indistinguishable from that of $D$. nanus using the classical cytogenetic techniques employed here. Therefore, our data corroborate the proposal of synonymy of D. walfordi and D. nanus presented by Lutz [23] and Duellman [24]. However, further studies that include other DNA sequences, such as $16 \mathrm{~S}$ rDNA and COI sequences, and other source of data are still necessary to conduct a proper taxonomic review of this issue.

Finally, our phylogenetic analyses did not cluster the specimens of $D$. elianeae according to their geographical range and no cytogenetic variation was detected among the specimens of $D$. elianeae from Botucatu-SP, Nova Itapirema-SP and Serra da Bodoquena-MS, which are localities that correspond to those of the geographic morphotypes SSP (southern São Paulo), NSP (northern São Paulo) and CBR (central Brazil), respectively, recognized by Napoli and Caramaschi [25]. In addition, it is worth noting that the $12 \mathrm{~S}$ rDNA sequence of a specimen previously assigned to D. rubicundulus [GenBank: AY843661] [1] was clustered among the sequences of $D$. elianeae in all of our phylogenetic analyses. This finding raises doubts regarding the taxonomic identification of that $D$. rubicundulus specimen. Unfortunately, other specimens of $D$. rubicundulus could not be included in our analyses, so further studies are necessary to clarify this issue.

The karyotype reported here for the D. elianeae specimens is most likely the same as that previously described by Gruber et al. [11] for specimens of D. elianeae from the Rio Claro municipality in southern São Paulo state, despite the distinct numeric classification of some chromosome pairs. Because several of the chromosomes in this karyotype are sufficiently similar in terms of size and centromeric position and could not be differentiated by any specific marker (differential C-band, for example), the attribution of a numeric classification to the chromosomes of this karyotype is a difficult task that results in only a tentative arrangement of the chromosome pairs. Therefore, the differences in the numeric classification of the chromosomes between the $D$. elianeae karyotype described by Gruber et al. [11] and that presented here most likely do not constitute real cytogenetic differences.

Another apparent difference between the D. elianeae karyotype described by Gruber et al. [11] and the karyotype presented here involves the morphological classification of the NOR-bearing chromosome. Gruber et al. [11] classified this chromosome as telocentric but also reported the presence of a NOR in its short arm. Because we measured all of the NOR-bearing chromosomes in which the secondary constriction of the NOR could be easily identified, we consider this chromosome to be subtelocentric, but it is most likely the same chromosome that carries the NOR in the 


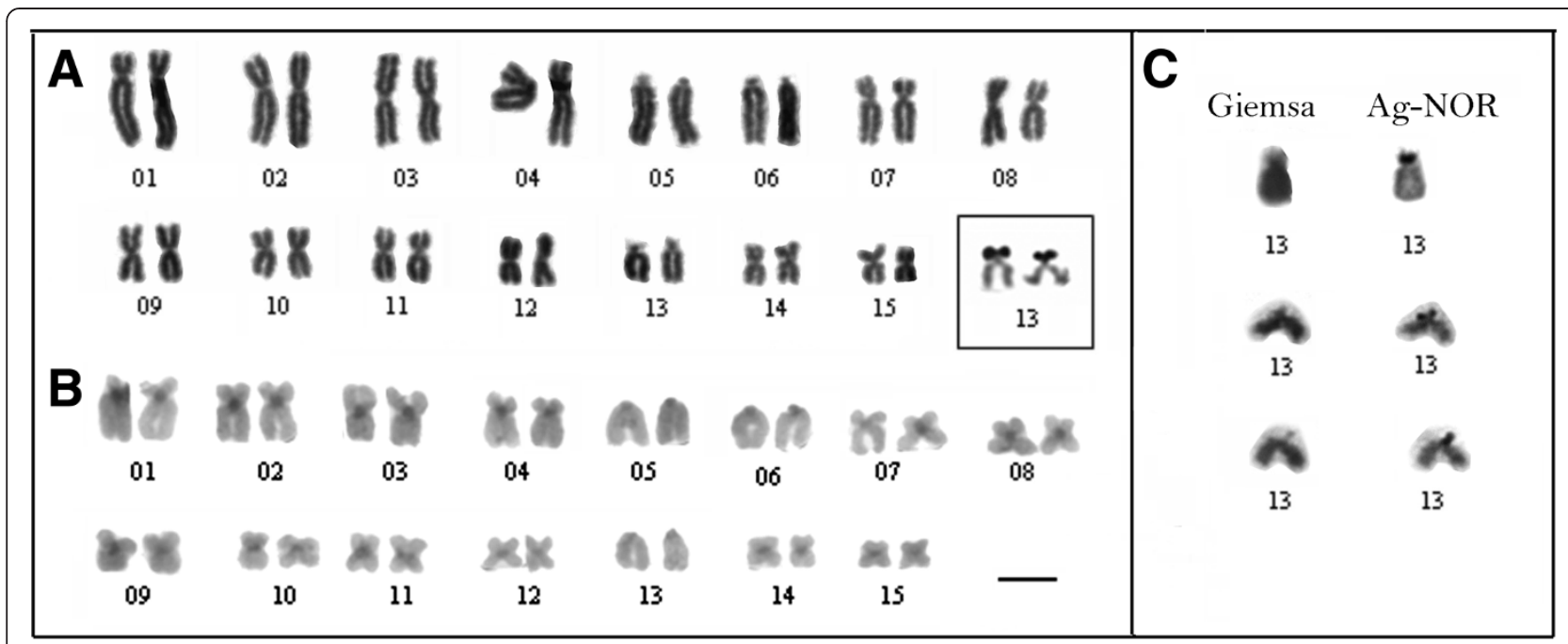

Figure 5 Karyological data of Dendropsophus elianeae. Karyotype arranged from Giemsa-stained (A) and C-banded metaphases (B) of Dendropsophus elianeae. The inset in A shows the Ag-stained NOR-bearing chromosome pair 13. In C, NOR-bearing chromosomes of D. elianeae after Giemsa staining (left) and sequential Ag-staining (right) are shown. Bar $=5 \mu \mathrm{m}$.

karyotype described by Gruber et al. [11]. In addition, by mapping the karyotype fundamental numbers on the phylogenies (Figures 1,2), we may consider the karyotype of $D$. elianeae to be derived from an ancestral karyotype with FN $=50$ similar to those found in $D$. jimi and D. sanborni. Otherwise, neither the homeology between the telocentric chromosomes of the above-mentioned species nor the possible rearrangement that might have resulted in the presumed FN increase can be elucidated.

Therefore, neither the cytogenetic data nor the phylogenetic analyses presented here were able to corroborate the geographic variation reported by Napoli and Caramaschi [24] for the species D. elianeae. Further studies including DNA markers that are more informative for this scale of analysis, such as $16 \mathrm{~S}$ rDNA, COI gene and microsatellite sequence markers, could be very useful in this case.

\section{Conclusions}

In conclusion, we observed that while in some cases the obtained cytogenetic data do not help to distinguish between valid species of Dendropsophus (such as D. jimi and D. sanborni), in others, the number of telocentric chromosomes clearly differs interspecifically, which can be useful in taxonomic analyses (such as for D. nanus and D. sanborni). Despite the interesting variation in the karyotypic fundamental number found in Dendropsophus, it is not yet possible to make a clear inference of homeology between the telocentric chromosomes of different species because several chromosomes of each karyotype have been found to be very similar based on analyses using the most commonly employed cytogenetic techniques. Therefore, the current numerical classifications of the chromosomes in the
Dendropsophus karyotypes do not reflect interspecific chromosomal homeologies and, in most cases, the inference of homeology between the telocentric chromosomes of different species is merely speculative. Thus, to allow for the formulation of a proposal regarding the chromosomal rearrangements involved in the karyotypic differentiation of the Dendropsophus species, further descriptions of new chromosomal markers and elucidation of the phylogeny of this genus are still necessary.

The above considerations regarding the homeology of chromosomal characters were only possible because the cytogenetic data were analyzed in the light of phylogenetic inferences. Therefore, this could be an interesting approach to analyze the evolution of chromosomal data, even when the available karyotypes are not sufficient for generating proper phylogenetic inferences by themselves.

\section{Methods}

\section{Taxon sampling}

Specimens of D. elianeae, D. jimi, D. nanus, D. sanborni and $D$. walfordi from localities ranging from the extreme south to the north of Brazil were used in cytogenetic and phylogenetic analyses. The sampled $D$. elianeae individuals included specimens from central Brazil (Serra da Bodoquena-MS), Minas Gerais state (Uberlândia municipality), and southern (Botucatu municipality) and northern (Nova Itapirema and Vitória Brasil municipalities) areas of São Paulo state (Table 1). The phylogenetic analyses also included $12 \mathrm{~S}$ rDNA sequences from specimens of $D$. anataliasiasi and $D$. minutus. The animals were collected and submitted to euthanasia under permit issued by the Instituto Brasileiro do Meio Ambiente e dos Recursos Naturais Renováveis (IBAMA, processes 
Table 1 Specimens included in the analyses

\begin{tabular}{|c|c|c|c|c|c|c|}
\hline Taxon & $\begin{array}{l}\text { Voucher } \\
\text { number }\end{array}$ & $\begin{array}{l}\text { Sex } \\
\text { (M:male; F: female) }\end{array}$ & Locality & $\begin{array}{l}\text { Cytogenetic } \\
\text { analysis }\end{array}$ & $\begin{array}{l}\text { GenBank } \\
\text { accession } \\
\text { number }\end{array}$ & Reference \\
\hline \multicolumn{7}{|c|}{ D. microcephalus group } \\
\hline D. anataliasiasi & ZUEC13138 & M & Porto Nacional, Tocantins, Brazil & - & $J \times 287452$ & This work \\
\hline D. anataliasiasi & ZUEC13139 & M & Porto Nacional, Tocantins, Brazil & - & $J \times 287453$ & This work \\
\hline D. anataliasiasi & ZUEC13140 & M & Porto Nacional, Tocantins, Brazil & - & $J \times 287454$ & This work \\
\hline D. berthalutzae & CFBH 5418 & & Duque de Caxias, RJ, Brazil & - & AY843607 & [1] Faivovich et al. (2005) \\
\hline D. bipunctatus & MRT5946 & & Serra do Teimoso, Jussari, Bahia, Brazil & - & AY843608 & [1] Faivovich et al. (2005) \\
\hline D. elianeae & ZUEC12455 & M & Uberlândia, Minas Gerais, Brazil & - & $J \times 287455$ & This work \\
\hline D. elianeae & ZUEC12459 & M & Uberlândia, Minas Gerais, Brazil & Yes & - & This work \\
\hline D. elianeae & ZUEC12460 & M & Uberlândia, Minas Gerais, Brazil & Yes & $J \times 287458$ & This work \\
\hline D. elianeae & ZUEC13130 & M & Uberlândia, Minas Gerais, Brazil & - & $J \times 287456$ & This work \\
\hline D. elianeae & ZUEC13131 & M & Uberlândia, Minas Gerais, Brazil & - & $J \times 287457$ & This work \\
\hline D. elianeae & ZUEC12273 & M & Botucatu, São Paulo, Brazil & Yes & - & This work \\
\hline D. elianeae & ZUEC12274 & M & Botucatu, São Paulo, Brazil & Yes & - & This work \\
\hline D. elianeae & ZUEC12275 & M & Botucatu, São Paulo, Brazil & Yes & $J \times 287401$ & This work \\
\hline D. elianeae & ZUEC12276 & M & Botucatu, São Paulo, Brazil & Yes & JX287402 & This work \\
\hline D. elianeae & ZUEC12277 & M & Botucatu, São Paulo, Brazil & Yes & $J \times 287403$ & This work \\
\hline D. elianeae & SMRP128.1 & M & Botucatu, São Paulo, Brazil & Yes & - & This work \\
\hline D. elianeae & SMRP128.2 & M & Botucatu, São Paulo, Brazil & Yes & - & This work \\
\hline D. elianeae & SMRP128.3 & M & Botucatu, São Paulo, Brazil & Yes & - & This work \\
\hline D. elianeae & SMRP128.6 & M & Nova Itapirema, São Paulo, Brazil & Yes & - & This work \\
\hline D. elianeae & DZSJRP7964 & M & Nova Itapirema, São Paulo, Brazil & Yes & JX287406 & This work \\
\hline D. elianeae & DZSJRP7965 & M & Nova Itapirema, São Paulo, Brazil & Yes & $J \times 287405$ & This work \\
\hline D. elianeae & DZSJRP7966 & M & Nova Itapirema, São Paulo, Brazil & Yes & $J \times 287404$ & This work \\
\hline D. elianeae & DZSJRP7967 & M & Vitória Brasil, São Paulo, Brazil & - & $J \times 287412$ & This work \\
\hline D. elianeae & DZSJRP7968 & M & Vitória Brasil, São Paulo, Brazil & - & $J X 287411$ & This work \\
\hline D. elianeae & DZSJRP7969 & M & Vitória Brasil, São Paulo, Brazil & - & $J \times 287410$ & This work \\
\hline D. elianeae & ZUEC12465 & M & Serra da Bodoquena, Mato Grosso do Sul, Brazil & Yes & $J \times 287407$ & This work \\
\hline D. elianeae & ZUEC12466 & M & Serra da Bodoquena, Mato Grosso do Sul, Brazil & Yes & - & This work \\
\hline D. elianeae & ZUEC12467 & M & Serra da Bodoquena, Mato Grosso do Sul, Brazil & Yes & $J \times 287408$ & This work \\
\hline D. elianeae & ZUEC12468 & M & Serra da Bodoquena, Mato Grosso do Sul, Brazil & Yes & $J \times 287409$ & This work \\
\hline D. elianeae & ZUEC12469 & M & Serra da Bodoquena, Mato Grosso do Sul, Brazil & Yes & - & This work \\
\hline
\end{tabular}


Table 1 Specimens included in the analyses (Continued)

\begin{tabular}{|c|c|c|c|c|c|c|}
\hline D. elianeae & ZUEC12470 & M & Serra da Bodoquena, Mato Grosso do Sul, Brazil & Yes & - & This work \\
\hline D. jimi & ZUEC13468 & M & Botucatu, São Paulo, Brazil, Brazil & - & $J \times 287413$ & This work \\
\hline D. jimi & ZUEC13469 & M & Botucatu, São Paulo, Brazil & - & JX287414 & This work \\
\hline D. jimi & ZUEC13470 & M & Botucatu, São Paulo, Brazil & - & $J X 287415$ & This work \\
\hline D. jimi & ZUEC12401 & M & Uberlândia, Minas Gerais, Brazil & Yes & - & This work \\
\hline D. jimi & ZUEC12402 & M & Uberlândia, Minas Gerais, Brazil & Yes & - & This work \\
\hline D. jimi & ZUEC12403 & M & Uberlândia, Minas Gerais, Brazil & Yes & - & This work \\
\hline D. jimi & ZUEC12404 & M & Uberlândia, Minas Gerais, Brazil & Yes & $J X 287416$ & This work \\
\hline D. jimi & ZUEC12405 & M & Uberlândia, Minas Gerais, Brazil & Yes & - & This work \\
\hline D. jimi & ZUEC12406 & M & Uberlândia, Minas Gerais, Brazil & Yes & JX287417 & This work \\
\hline D. jimi & ZUEC12407 & M & Uberlândia, Minas Gerais, Brazil & Yes & $J X 287418$ & This work \\
\hline D. jimi & ZUEC12408 & M & Uberlândia, Minas Gerais, Brazil & Yes & - & This work \\
\hline D. jimi & ZUEC12463 & M & Uberlândia, Minas Gerais, Brazil & Yes & - & This work \\
\hline D. jimi & ZUEC12464 & M & Uberlândia, Minas Gerais, Brazil & Yes & - & This work \\
\hline D. jimi & ZUEC12305 & M & Uberlândia, Minas Gerais, Brazil & Yes & - & This work \\
\hline D. jimi & ZUEC12306 & M & Uberlândia, Minas Gerais, Brazil & Yes & - & This work \\
\hline D. jimi & ZUEC12307 & M & Uberlândia, Minas Gerais, Brazil & Yes & - & This work \\
\hline D. jimi & ZUEC12308 & M & Uberlândia, Minas Gerais, Brazil & Yes & - & This work \\
\hline D. jimi & ZUEC12309 & M & Uberlândia, Minas Gerais, Brazil & Yes & - & This work \\
\hline D. jimi & ZUEC12310 & M & Uberlândia, Minas Gerais, Brazil & Yes & - & This work \\
\hline D. leali & KU 215259 & - & Cuzco Amazonico, Madre de Dios, Peru & - & AY819451 & [28] Wiens et al. (2005) \\
\hline D. microcephalus & UTA 50632 & - & Atlantida, Honduras & - & AY819371 & [28] Wiens et al. (2005) \\
\hline D. microcephalus & UTA A-50632 & - & Atlantida, Honduras & - & AY843643 & [1] Faivovich et al. (2005) \\
\hline D. microcephalus & MVZ203881 & - & Guanacaste, Costa Rica & - & EF566945 & Unpublished \\
\hline D. minusculus & - & - & - & - & EF376025 & Unpublished \\
\hline D. minutus & ZUEC12409 & M & Serra da Bodoquena, Mato Grosso do Sul, Brazil & - & JX287424 & This work \\
\hline D. minutus & ZUEC12410 & M & Serra da Bodoquena, Mato Grosso do Sul, Brazil & - & $J X 287425$ & This work \\
\hline D. minutus & ZUEC12411 & M & Serra da Bodoquena, Mato Grosso do Sul, Brazil & - & JX287426 & This work \\
\hline D. minutus & ZUEC13191 & M & Campinas, São Paulo, Brazil & - & $J X 287421$ & This work \\
\hline D. minutus & ZUEC13193 & M & Campinas, São Paulo,Brazil & - & JX287422 & This work \\
\hline D. minutus & ZUEC18133 & M & Campinas, São Paulo, Brazil & - & $J \times 287423$ & This work \\
\hline D. minutus & ZUEC12414 & M & Nova Itapirema, São Paulo, Brazil & - & $J X 287419$ & This work \\
\hline D. minutus & ZUEC12415 & M & Nova Itapirema, São Paulo, Brazil & - & $J \times 287420$ & This work \\
\hline
\end{tabular}


Table 1 Specimens included in the analyses (Continued)

\begin{tabular}{|c|c|c|c|c|c|c|}
\hline D. minutus & SMRP171.1 & $M$ & Telêmaco Borba, Paraná, Brazil & - & $J X 287429$ & This work \\
\hline D. minutus & SMRP171.2 & M & Telêmaco Borba, Paraná, Brazil & - & $J \times 287428$ & This work \\
\hline D. minutus & SMRP171.3 & M & Telêmaco Borba, Paraná, Brazil & - & JX287427 & This work \\
\hline D. minutus & DZSJRP7970 & M & Vitória Brasil, São Paulo, Brazil & - & $J \times 287430$ & This work \\
\hline D. minutus & DZSJRP7975 & M & Vitória Brasil, São Paulo, Brazil & - & JX287431 & This work \\
\hline D. minutus & DZSJRP7976 & M & Vitória Brasil, São Paulo, Brazil & - & $J X 287432$ & This work \\
\hline D. nanus & SMRP47.2 & - & Nova Itapirema, São Paulo, Brazil & - & $J \times 287443$ & This work \\
\hline D. nanus & SMRP47.3 & - & Nova Itapirema, São Paulo, Brazil & - & JX287444 & This work \\
\hline D. nanus & SMRP47.4 & - & Nova Itapirema, São Paulo, Brazil & - & JX287445 & This work \\
\hline D. nanus & ZUEC11416 & - & Nova Itapirema, São Paulo, Brazil & - & $J X 287446$ & This work \\
\hline D. nanus & SMRP47.12 & M & Nova Itapirema, São Paulo, Brazil & - & JX287447 & This work \\
\hline D. nanus & SMRP47.20 & M & Nova Itapirema, São Paulo, Brazil & - & JX287448 & This work \\
\hline D. nanus & ZUEC12261 & M & Botucatu, São Paulo, Brazil & Yes & $J X 287438$ & This work \\
\hline D. nanus & ZUEC12265 & M & Botucatu, São Paulo, Brazil & Yes & $J X 287439$ & This work \\
\hline D. nanus & ZUEC12392 & $\mathrm{F}$ & $\begin{array}{l}\text { Serra da Bodoquena, Mato Grosso } \\
\text { do Sul, Brazil }\end{array}$ & & $J X 287475$ & This work \\
\hline D. nanus & ZUEC12393 & $\mathrm{F}$ & $\begin{array}{l}\text { Serra da Bodoquena, Mato Grosso } \\
\text { do Sul, Brazil }\end{array}$ & & $J \times 287474$ & This work \\
\hline D. nanus & ZUEC13179 & M & $\begin{array}{l}\text { Serra da Bodoquena, Mato Grosso } \\
\text { do Sul, Brazil }\end{array}$ & Yes & $J X 287476$ & This work \\
\hline D. nanus & ZUEC13180 & M & $\begin{array}{l}\text { Serra da Bodoquena, Mato Grosso } \\
\text { do Sul, Brazil }\end{array}$ & Yes & $J X 287477$ & This work \\
\hline D. nanus & ZUEC11899 & $\mathrm{F}$ & $\begin{array}{l}\text { Corumbá, Mato Grosso do Sul, } \\
\text { Brazil }\end{array}$ & - & $J X 287436$ & This work \\
\hline D. nanus & ZUEC11904 & M & Corumbá, Mato Grosso do Sul, Brazil & - & JX287437 & This work \\
\hline D. nanus & ZUEC11879 & M & Bacabal, Maranhão, Brazil & - & $J X 287433$ & This work \\
\hline D. nanus & ZUEC11886 & M & Bacabal, Maranhão, Brazil & - & $J X 287434$ & This work \\
\hline D. nanus & ZUEC11887 & M & Bacabal, Maranhão, Brazil & - & $J X 287435$ & This work \\
\hline D. nanus & ZUEC12214 & $?$ & Castanho, Amazonas, Brazil & - & $J X 287440$ & This work \\
\hline D. nanus & ZUEC12215 & $?$ & Castanho, Amazonas, Brazil & - & $J X 287441$ & This work \\
\hline D. nanus & ZUEC12217 & $?$ & Castanho, Amazonas, Brazil & - & JX287442 & This work \\
\hline D. nanus & ZUEC12382 & M & Telêmaco Borba, Paraná, Brazil & Yes & - & This work \\
\hline D. nanus & ZUEC12383 & M & Telêmaco Borba, Paraná, Brazil & Yes & JX287449 & This work \\
\hline D. nanus & ZUEC12384 & M & Telêmaco Borba, Paraná, Brazil & Yes & $J \times 287450$ & This work \\
\hline D. nanus & ZUEC12385 & M & Telêmaco Borba, Paraná, Brazil & Yes & - & This work \\
\hline
\end{tabular}


Table 1 Specimens included in the analyses (Continued)

\begin{tabular}{|c|c|c|c|c|c|c|}
\hline D. nanus & ZUEC12386 & M & Telêmaco Borba, Paraná, Brazil & Yes & - & This work \\
\hline D. nanus & ZUEC12387 & M & Telêmaco Borba, Paraná, Brazil & Yes & - & This work \\
\hline D. nanus & ZUEC12388 & M & Telêmaco Borba, Paraná, Brazil & Yes & - & This work \\
\hline D. nanus & ZUEC12389 & M & Telêmaco Borba, Paraná, Brazil & Yes & - & This work \\
\hline D. nanus & ZUEC12390 & $\mathrm{F}$ & Telêmaco Borba, Paraná, Brazil & Yes & $J X 287451$ & This work \\
\hline D. nanus & ZUEC12391 & M & Telêmaco Borba, Paraná, Brazil & Yes & - & This work \\
\hline D. nanus & $\begin{array}{l}\text { USNM-Field } \\
\text { Number } 53122\end{array}$ & & $\begin{array}{l}\text { South of Luiz Antonio, São } \\
\text { Paulo, Brazil }\end{array}$ & - & AY819373 & $\begin{array}{l}\text { [28] Wiens } \\
\text { et al. (2005) }\end{array}$ \\
\hline D. nanus & MACN 37785 & & $\begin{array}{l}\text { Dto. Islas del Ibicuy, Entre Rios, } \\
\text { Argentina }\end{array}$ & - & AY549346 & [30] Faivovich et al. (2004) \\
\hline D. nanus & - & - & - & - & $E F 376026^{a}$ & Unpublished \\
\hline D. rhodopeplus & MHZ 462 & & Loreto, Peru & - & AY843658 & [1] Faivovich et al. (2005) \\
\hline D. rhodopeplus & KU 221906 & & Loreto, Peru & - & DQ380371 & [31] Wiens et al. (2006) \\
\hline D. robertmertensi & MZFC 15824 & & Oaxaca, Mexico & - & AY819452 & [28] Wiens et al. (2005) \\
\hline D. rubicundulus ${ }^{b}$ & IT-H 0653 & & Buri, São Paulo, Brazil & - & AY843661 & [1] Faivovich et al. (2005) \\
\hline D. sanborni & SMRP48.23 & M & Nova Itapirema, São Paulo, Brazil & - & $J \times 287459$ & This work \\
\hline D. sanborni & SMRP48.25 & M & Nova Itapirema, São Paulo, Brazil & - & $J \times 287460$ & This work \\
\hline D. sanborni & SMRP48.26 & M & Nova Itapirema, São Paulo, Brazil & - & $J \times 287461$ & This work \\
\hline D. sanborni & ZUEC12416 & M & Salesópolis, São Paulo, Brazil & Yes & JX287462 & This work \\
\hline D. sanborni & ZUEC12417 & M & Salesópolis, São Paulo, Brazil & Yes & $J \times 287463$ & This work \\
\hline D. sanborni & ZUEC12419 & M & Salesópolis, São Paulo, Brazil & Yes & $J \times 287464$ & This work \\
\hline D. sanborni & ZUEC12433 & M & Botucatu, São Paulo, Brazil & Yes & JX287465 & This work \\
\hline D. sanborni & ZUEC12434 & M & Botucatu, São Paulo, Brazil & Yes & & This work \\
\hline D. sanborni & ZUEC12435 & M & Botucatu, São Paulo, Brazil & Yes & & This work \\
\hline D. sanborni & ZUEC12436 & M & Botucatu, São Paulo, Brazil & Yes & & This work \\
\hline D. sanborni & ZUEC12437 & M & Botucatu, São Paulo, Brazil & Yes & & This work \\
\hline D. sanborni & ZUEC12438 & M & Botucatu, São Paulo, Brazil & Yes & JX287466 & This work \\
\hline D. sanborni & ZUEC12439 & $\mathrm{F}$ & Botucatu, São Paulo, Brazil & Yes & & This work \\
\hline D. sanborni & ZUEC12440 & M & Botucatu, São Paulo, Brazil & Yes & & This work \\
\hline D. sanborni & ZUEC12441 & M & Botucatu, São Paulo, Brazil & Yes & & This work \\
\hline D. sanborni & ZUEC12442 & M & Botucatu, São Paulo, Brazil & Yes & & This work \\
\hline D. sanborni & ZUEC12443 & M & Botucatu, São Paulo, Brazil & Yes & $J \times 287467$ & This work \\
\hline D. sanborni & ZUEC12444 & M & Botucatu, São Paulo, Brazil & Yes & & This work \\
\hline D. sanborni & ZUEC12445 & M & Botucatu, São Paulo, Brazil & Yes & & This work \\
\hline
\end{tabular}


Table 1 Specimens included in the analyses (Continued)

\begin{tabular}{|c|c|c|c|c|c|c|}
\hline D. sanborni & ZUEC12446 & M & Botucatu, São Paulo, Brazil & Yes & & This work \\
\hline D. sanborni & ZUEC12447 & M & Botucatu, São Paulo, Brazil & Yes & & This work \\
\hline D. sanborni & ZUEC12448 & M & Botucatu, São Paulo, Brazil & Yes & & This work \\
\hline D. sanborni & ZUEC12449 & M & Botucatu, São Paulo, Brazil & Yes & & This work \\
\hline D. sanborni & ZUEC12450 & M & Botucatu, São Paulo, Brazil & Yes & & This work \\
\hline D. sanborni & ZUEC12451 & M & Botucatu, São Paulo, Brazil & Yes & & This work \\
\hline D. sanborni & ZUEC12452 & $\mathrm{F}$ & Botucatu, São Paulo, Brazil & Yes & & This work \\
\hline D. sanborni & ZUEC12453 & M & Botucatu, São Paulo, Brazil & Yes & & This work \\
\hline D. sanborni & ZUEC13457 & M & Torres, Rio Grande do Sul, Brazil & Yes & $J X 287468$ & This work \\
\hline D. sanborni & ZUEC13460 & M & Torres, Rio Grande do Sul, Brazil & Yes & $J X 287469$ & This work \\
\hline D. sanborni & ZUEC13461 & M & Torres, Rio Grande do Sul, Brazil & Yes & $J X 287470$ & This work \\
\hline D. sanborni & MACN 38638 & & $\begin{array}{l}\text { Dto. Islas del Ibicuy, Entre Rios, } \\
\text { Argentina }\end{array}$ & - & AY843663 & [1] Faivovich et al. (2005) \\
\hline D. sartori & MZFC 16014 & & Guerrero, Mexico & - & AY819453 & [28] Wiens et al. (2005) \\
\hline D. walfordi & ZUEC12190 & M & Guajará Mirim, Roraima Brazil $^{c}$ & Yes & & This work \\
\hline D. walfordi & ZUEC12191 & M & Guajará Mirim, Roraima Brazil ${ }^{c}$ & Yes & & This work \\
\hline D. walfordi & ZUEC12192 & M & 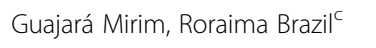 & Yes & $J \times 287472$ & This work \\
\hline D. walfordi & ZUEC12193 & M & Guajará Mirim, Roraima Brazil ${ }^{c}$ & Yes & $J X 287471$ & This work \\
\hline D. walfordi & ZUEC12194 & M & Guajará Mirim, Roraima Brazil ${ }^{c}$ & Yes & $J \times 287473$ & This work \\
\hline D. walfordi & ZUEC12195 & M & Guajará Mirim, Roraima Brazil $^{c}$ & Yes & & This work \\
\hline D. walfordi & ZUEC12196 & M & Guajará Mirim, Roraima Brazil $^{c}$ & Yes & & This work \\
\hline D. walfordi & ZUEC12197 & M & 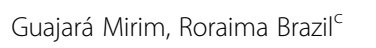 & Yes & & This work \\
\hline D. walfordi & ZUEC12198 & M & Guajará Mirim, Roraima Brazil $^{c}$ & Yes & & This work \\
\hline D. walfordi & ZUEC12199 & M & Guajará Mirim, Roraima Brazil $^{c}$ & Yes & & This work \\
\hline D. walfordi & ZUEC12200 & M & 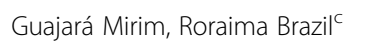 & Yes & & This work \\
\hline D. walfordi & ZUEC12201 & M & Guajará Mirim, Roraima Brazil $^{c}$ & Yes & & This work \\
\hline D. walfordi & ZUEC12202 & M & Guajará Mirim, Roraima Brazil $^{c}$ & Yes & & This work \\
\hline D. walfordi & ZUEC12203 & M & 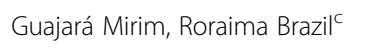 & Yes & & This work \\
\hline D. walfordi & ZUEC12204 & M & Guajará Mirim, Roraima Brazil ${ }^{c}$ & Yes & & This work \\
\hline D. walfordi & ZUEC12205 & M & Guajará Mirim, Roraima Brazil ${ }^{c}$ & Yes & & This work \\
\hline D. walfordi & MJH 129 & & Brazil & - & AY843683 & [1] Faivovich et al. (2005) \\
\hline D. aff. cruzi & SMRP193.2 & M & Porto Nacional, Tocantins, Brazil & - & JX287398 & This work \\
\hline D. aff. cruzi & SMRP193.3 & M & Porto Nacional, Tocantins, Brazil & - & JX287399 & This work \\
\hline D. aff. cruzi & SMRP193.4 & M & Porto Nacional, Tocantins, Brazil & - & $J X 287400$ & This work \\
\hline
\end{tabular}


Table 1 Specimens included in the analyses (Continued)

\begin{tabular}{|c|c|c|c|c|c|c|}
\hline \multicolumn{7}{|c|}{ Other groups of Dendropsophus } \\
\hline D. allenorum & KU 215190 & - & $\begin{array}{l}\text { Cuzco Amazonico, Madre } \\
\text { de Dios, Peru }\end{array}$ & - & DQ380348 & [31] Wiens et al. (2006) \\
\hline D. anceps & CFBH 5797 & - & Linhares, Espírito Santo, Brazil & - & AY843597 & [1] Faivovich et al. (2005) \\
\hline D. aperomeus & KU 212083 & - & Rioja, San Martin, Peru & - & AY819450 & [28] Wiens et al. (2005) \\
\hline D. bifurcus & - & - & - & - & AY362975 & Jungfer et al. (2010) \\
\hline D. bifurcus & KU 217514 & - & Limon, Morona-Santiago, Ecuador & - & DQ380350 & [31] Wiens et al. (2006) \\
\hline D. brevifrons & MJH 7101 & - & Huanuco, Rio Llullapichis, Panguana, Peru & - & AY843611 & [1] Faivovich et al. (2005) \\
\hline D. brevifrons & WED 58779 & - & Napo, Ecuador & - & DQ380351 & [31] Wiens et al. (2006) \\
\hline D. carnifex & KU 218300 & - & Pichincha, Ecuador & - & AY819424 & [28] Wiens et al. (2005) \\
\hline D. carnifex & DFCH-USFQ 899 & - & Pichincha, Ecuador & - & AY843616 & [1] Faivovich et al. (2005) \\
\hline D. ebraccatus & UTA 51789 & - & $\begin{array}{l}\text { Mataglpa, Comarca Penas } \\
\text { Blancas,Finca San Sebastian, Nicaragua }\end{array}$ & - & AY819367 & [28] Wiens et al. (2005) \\
\hline D. ebraccatus & RdS 790 & - & Stann Creek District, Belize & - & AY843624 & [1] Faivovich et al. (2005) \\
\hline D. elegans & LM 3135 & - & & - & DQ380355 & [31] Wiens et al. (2006) \\
\hline D. giesleri & CFBH S/N & - & $\begin{array}{l}\text { Ubatuba (Picinguaba), São Paulo, } \\
\text { Brazil }\end{array}$ & - & AY843629 & [1] Faivovich et al. (2005) \\
\hline D. koechlini & KU 215248 & - & $\begin{array}{l}\text { Cuzco Amazonico, Madre de } \\
\text { Dios, Peru }\end{array}$ & - & AY819369 & [28] Wiens et al. (2005) \\
\hline D. labialis & QULC 97005 & - & $\begin{array}{l}\text { Parque Natural Nacional } \\
\text { Chingaza, Colombia }\end{array}$ & - & AY843635 & [1] Faivovich et al. (2005) \\
\hline D. leucophyllatus & KU 215274 & - & Cuzco Amazonico, Madre de Dios, Peru & - & DQ380360 & [31] Wiens et al. (2006) \\
\hline D. marmoratus & MJH 7116 & - & Huanuco, Rio Llullapichis, Panguana, Peru & - & AY843640 & [1] Faivovich et al. (2005) \\
\hline D. marmoratus & USNM 317326 & - & Vicinity of Huampami, Amazonas, Peru & - & AY819432 & [28] Wiens et al. (2005) \\
\hline D. miyatai & JPC 10772; LSUMZ H-12939 & - & Sucumbios, Ecuador & - & AY843647 & [1] Faivovich et al. (2005) \\
\hline D. parviceps & AMNH A-139315 & - & Centro Experimental da UFAC, Acre, Brazil & - & AY843652 & [1] Faivovich et al. (2005) \\
\hline D. parviceps & WED 50309 & - & & - & DQ380367 & [31] Wiens et al. (2006) \\
\hline D. pelidna & KU 181108 & - & Betania, Tachira, Venezuela & - & AY819434 & [28] Wiens et al. (2005) \\
\hline D. riveroi & KU 217613 & - & Sucumbios, Ecuador & - & DQ380372 & [31] Wiens et al. (2006) \\
\hline D. salli & & - & & - & AY362976 & [32] Jungfer et al. (2010) \\
\hline D. sarayacuensis & KU 221916 & - & Teniente Lopez, Loreto, Peru & - & DQ380373 & [31] Wiens et al. (2006) \\
\hline D. schubarti & WED 57619 & - & & - & DQ380374 & [31] Wiens et al. (2006) \\
\hline D. seniculus & CFBH 5761 & - & Angra dos Reis, Rio de Janeiro, Brazil & - & AY843666 & [1] Faivovich et al. (2005) \\
\hline D. triangulum & KU 202745 & - & Misahualli, Napo, Ecuador & - & AY326053 & $\begin{array}{l}\text { [33] Darst \& Cannatella } \\
\text { (2004) }\end{array}$ \\
\hline
\end{tabular}


Table 1 Specimens included in the analyses (Continued)

\begin{tabular}{|c|c|c|c|c|c|c|}
\hline D. triangulum & MJH 3844 & - & Lago Catalao, Acre, Brazil & - & AY843680 & [1] Faivovich et al. (2005) \\
\hline D. triangulum & KU 217664 & - & Sucumbios, Ecuador & - & DQ380377 & [31] Wiens et al. (2006) \\
\hline \multicolumn{7}{|l|}{ Other genera } \\
\hline Scarthyla goinorum & KU 215423 & - & & - & AY819389 & [28] Wiens et al. (2005) \\
\hline Scarthyla goinorum & QULC 2340 & - & Igarape Nova Empresa, Amazonas, Brazil & - & AY843752 & [1] Faivovich et al. (2005) \\
\hline $\begin{array}{l}\text { Scarthyla goinorum } \\
\text { (= S. ostinodactyla) }\end{array}$ & KU 205763 & - & Cuzco Amazonico, Madre de Dios, Peru & - & AY326035 & $\begin{array}{l}\text { [33] Darst \& Cannatella } \\
\text { (2004) }\end{array}$ \\
\hline Xenohyla truncata & CFBH 7600 & - & Restinda de Marica, Rio de Janeiro, Brazil & - & AY843775 & [1] Faivovich et al. (2005) \\
\hline $\begin{array}{l}\text { Phyllodytes } \\
\text { luteolus }\end{array}$ & & - & Guarapari, Sepetiba, Brazil & - & DQ403729 & Unpublished \\
\hline Pseudis minuta & MACN 37786 & - & Dto. Islas del Ibicuy, Entre Rios, Argentina & - & AY843739 & [1] Faivovich et al. (2005) \\
\hline
\end{tabular}

The type locality of $D$. walfordi, designated Forte Príncipe da Beira (see Frost, 2011, for references), is located in Guajará-Mirim, RO. 
10461 and 02001.008876/01-83). The voucher number and collection site of each of the specimens analyzed are indicated in Table 1.

Identification of all the specimens employed in the cytogenetic and phylogenetic analyses, their procedence and voucher number. The GenBank accession number of each DNA sequence and the specimens which were karyotyped are indicated. DZSJRP: Coleção Científica Amphibia Adults, Department of Zoologia e Botânica, Universidade Estadual Paulista (UNESP), São José do Rio Preto, São Paulo, Brazil; SMRP: Collection of tissue and chromosome preparation "Shirlei Maria Recco Pimentel", deposited at the Department of Structural and Functional Biology at the Biology Institute of the University of Campinas, Campinas, São Paulo, Brazil; ZUEC: Museu de Zoologia "Prof. Adão José Cardoso" (ZUEC), Universidade Estadual de Campinas (UNICAMP), Campinas, São Paulo, Brazil.

In the phylogenetic analyses, we included $12 \mathrm{~S}$ rDNA sequences (available in GenBank) from 30 species of Dendropsophus, as well as sequences from Xenohyla truncata, Pseudis minuta, Scarthyla goinorum and Phyllodytes luteolus, the last of which was used as the root (Table 1). We avoided the inclusion of short partial sequences (those with less than $50 \%$ of the length of the fragment of interest). The only exception was for a sequence of D. nanus from French Guiana (EF376026), a locality from which we could not sample.

\section{Chromosomal analysis}

The chromosome preparations were obtained from intestinal and testicular cell suspensions, as described by King and Rofe [34] or Schmid [35]. Prior to intestine and testes removal, the animals were deeply anesthetized. Chromosome preparations were stained with $10 \%$ Giemsa, processed for C-banding [36] and subjected to Ag-NOR staining [37] and fluorescent in situ hybridization (FISH) [38] with the rDNA probe HM123 [39] (except for D. elianeae). All chromosome preparations were analyzed under an Olympus BX60 microscope. The chromosomes were classified as proposed by Green and Sessions [27].

\section{DNA extraction, amplification and sequencing}

Genomic DNA was extracted from liver or muscle tissue stored at $-70^{\circ} \mathrm{C}$ in the tissue bank of the Department of Structural and Functional Biology-UNICAMP, Campinas, SP, Brazil, using the TNES method. Tissue samples were immersed in TNES buffer solution $(50 \mathrm{mM}$ Tris pH 7.5, $400 \mathrm{mM} \mathrm{NaCl}, 20 \mathrm{mM}$ EDTA, 0.5\% SDS). The solution was subsequently supplemented with proteinase $\mathrm{K}$ (to a final concentration of $100 \mu \mathrm{g} / \mathrm{mL}$ ), and the samples were incubated for 5 hours at $55^{\circ} \mathrm{C}$. Then, $1 / 3$ volume of $\mathrm{NaCl} 5 \mathrm{M}$ was added, and the samples were centrifuged. DNA was precipitated from the supernatant with isopropyl alcohol, washed with ethanol (70\%), resuspended in TE $(10 \mathrm{mM}$ Tris- $\mathrm{HCl}, 1 \mathrm{mM}$ EDTA $\mathrm{pH} 8.0)$ and stored at $-20^{\circ} \mathrm{C}$.

The mitochondrial $12 \mathrm{~S}$ ribosomal gene was partially amplified using the primers MVZ 59(L) and MVZ 50(H) [40]. The PCR-amplified products were purified with the GFX PCR and Gel Band DNA Purification Kits (GE Healthcare, England) and directly used as templates for sequencing in an automatic $\mathrm{ABI} /$ Prism DNA sequencer (Applied Biosystems, Foster City, CA, USA) using the BigDye Terminator Kit (Applied Biosystems, Foster City, CA, USA), as recommended by the manufacturer. DNA sequences were bi-directionally sequenced and edited using Bioedit version 7.0.1 (http://www.mbio.ncsu.edu/ BioEdit/bioedit.html).

\section{Phylogenetic inferences}

Fragments of approximately $810 \mathrm{bps}$ of the $12 \mathrm{~S}$ ribosomal genes from 80 specimens of Dendropsophus were sequenced as described above, and a data matrix consisting of 133 OTUs, including five sequences from outgroup species and a total of 37 species of Dendropsophus, was constructed. The GenBank accession numbers for all of the sequences used are presented in Table 1. Because parsimony [1] and likelihood [12,13] criteria have been employed for the phylogenetic studies of Dendropsophus, we conducted both types of analyses. When using parsimony criterion, phylogenetic relationships were inferred (i) from analyses under dynamic homology, as implemented in the software POY v.4.1.2.1 [41], or (ii) from aligned sequences using the software TNT v.1.1 [42]. A Bayesian analysis was implemented in the software MrBayes v.3.1.2 [43] using the model GTR $+\mathrm{I}+\mathrm{G}$, inferred with the software MrModeltest v.2.3 [44]. For the analyses using TNT and MrBayes, the sequences were first aligned with Clustal W [45], and a matrix was generated with 852 characters.

The phylogenetic searches performed with POY included tree building (of Wagner trees), tree bisection-reconnection (TBR) swapping, perturbation using a parsimony ratchet and tree fusing. The analyses were run with a maximum execution time of $48 \mathrm{~h}$ and an opening indel cost of 3 , indel extension cost of 1 and nucleotide substitution cost of 1 using the command "transform (tcm:(1, 1), gap_opening:2)". To obtain an implied alignment from the POY analysis, the characters were transformed into static characters, and the generated matrix was exported using the command "phastwinclad." The exported matrix was loaded with TNT v.1.1 to calculate the bootstrap support based on 1,000 pseudoreplicates.

For the phylogenetic analysis using TNT software, the most parsimonious trees were inferred through heuristic searches performed using the command xmult, which combined sectorial searches, the ratchet, tree drifting and 
tree fusing. Gaps were considered to be missing data. The bootstrap values of the branches inferred in this analysis were calculated with 1000 pseudoreplicates.

For the Bayesian inferences, two simultaneous analyses were run, each with four chains (three heated and one cold). In each analysis, 2,980,000 generations were run and one tree was sampled every 100 generations. A consensus topology and the posterior probability for each node were produced after discarding the first $25 \%$ of the trees generated. The ASDSF (Average Standard Deviation of Split Frequencies) value was below 0.01, and the PSRF (Potential Scale Reduction Factor) values were approximately 1.000 .

\section{Additional files}

Additional file 1: Figure S1. Strict consensus cladogram of four most parsimonious trees scored at 2195 inferred from TNT analyses of $12 \mathrm{~S}$ rDNA sequences. Numbers adjacent to nodes indicate bootstrap values. The karyotype fundamental number (FN) is indicated for some species. The asterisk indicates the node of the clade that includes the species of the $D$. microcephalus group.

Additional file 2: Figure S2. Topology inferred from Bayesian analysis of $12 \mathrm{~S}$ rDNA sequences. Numbers adjacent to nodes indicate posterior probabilities. The asterisk indicates the node of the clade that includes the species of the D. microcephalus group.

Additional file 3: Figure S3. Karyotype of the ZUEC 13179 specimen of D. nanus with $F N=53$. In A, Giemsa-stained karyotype arranged from the same metaphase which is shown in $\mathbf{B}$ after silver staining. Note the heteromorphic pair 6.

\section{Competing interests}

The authors declare that they have no competing interests.

\section{Authors' contributions}

LRM acquired the cytogenetic data and helped draft the manuscript. GTBTE acquired most of the DNA sequences. LBL acquired some of the cytogenetic data and DNA sequences, conducted the phylogenetic analyses and helped draft the manuscript. DCRF, APL, GVA and AAG helped collect and identified the specimens, provided support on zoological information and revised the manuscript. SMRP designed and coordinated the study and revised the manuscript. All authors read and approved the final manuscript.

\section{Acknowledgements}

The authors thank M. Uetanabaro, R. Machado, S. C. Almeida, G. Vinciprova and M. Menin for their help in collecting specimens; Julián Faivovich for reading the manuscript and providing useful comments; Alessandra F. Costa and Klélia A. Carvalho for technical assistance in slide preparation and some FISH experiments, respectively; and V. G. D. Orrico and B. F. Teixeira for helpful insights on the taxonomic identification of some specimens. This work was supported by the Brazilian agencies Conselho Nacional de Desenvolvimento Científico e Tecnológico (CNPq), Fundação de Amparo à Pesquisa do Estado de São Paulo (FAPESP, proc. 00/11031-4 and Proc. 03/04243-3) and Fundação de Amparo à Pesquisa do Estado de Minas Gerais (FAPEMIG).

\section{Author details}

'Departamento de Biologia Estrutural e Funcional, Instituto de Biologia, Universidade Estadual de Campinas (UNICAMP), 13086-863, Campinas, SP, Brazil. ²Departamento de Zoologia e Botânica, Instituto de Biociências, Letras e Ciências Exatas, Universidade Estadual Paulista (UNESP), 15054-000, São José do Rio Preto, São Paulo, Brazil. ${ }^{3}$ Coordenadoria de Pesquisas em Ecologia, Instituto Nacional de Pesquisas da Amazônia (INPA), 69011-970, Manaus, AM, Brazil. ${ }^{4}$ Departamento de Biologia, Centro de Ciências Biológicas e da Saúde, Universidade Federal do Maranhão (UFMA), Campus do Bacanga, 65080-040, São Luís, MA, Brazil. ${ }^{5}$ Laboratório de Anuros
Neotropicais, Faculdade de Ciências Integradas do Pontal, Universidade Federal de Uberlândia, 38304-402, Ituiutaba, MG, Brazil. ${ }^{6}$ Departamento de Polícia Federal, Ministério da Justiça, 68908-901, Macapá, AP, Brazil.

Received: 8 January 2013 Accepted: 20 June 2013

Published: 3 July 2013

\section{References}

1. Faivovich J, Haddad CFB, Garcia PCA, Frost DR, Campbell JA, Wheeler WC: Systematic review of the frog family Hylidae, with special reference to Hylinae: phylogenetic analysis and taxonomic revision. Bull Am Museum Nat Hist 2005, 294:1-240.

2. Frost DR: Amphibian Species of the World: an Online Reference. New York, USA: American Museum of Natural History. Version 5.5 (31 January, 2011). [Electronic Database accessible at http://research.amnh.org/vz/herpetology/amphibia/.

3. Beçak ML: Chromosomal analysis of eighteen species of Anura. Caryologia 1968, 21:191-208.

4. Rabello MN: Chromosomal studies in Brazilian anurans. Caryologia 1970, 23:45-59.

5. Foresti F: Aspectos cromossômicos da família Hylidae (Amphibia - Anura). ESALQ, Brazil: Master Dissertation. Universidade de São Paulo; 1972.

6. Bogart JP: Evolution of anuran karyotypes. In Evolutionary Biology of Anurans. Edited by Vial JL. Columbia: Missouri: Univ. Missouri Press; 1973:337-349.

7. Anderson K: Chromosome evolution in Holoarctic Hyla treefrogs. In Amphibian Cytogenetics and Evolution. Edited by Green DM, Sessions SK. San Diego: Academic; 1991:299-328.

8. Skuk G, Langone JA: Los cromosomas de cuatro especies del Género Hyla (Anura: Hylidae) com número diploide de $2 n=30$. Acta Zool Lilloana 1992, 41:165-171.

9. Kaiser H, Mais C, Bolaños F, Steinlein C, Feichtinger W, Schmid M: Chromosomal investigation of three Costa Rican frogs from the 30chromosome radiation of Hyla with the description of a unique geographic variation in nucleolus organizer regions. Genetica 1996, 98:95-102.

10. Medeiros LR, Rossa-Feres DC, Recco-Pimentel SM: Chromosomal differentiation of Hyla nana and Hyla sanborni (Anura, Hylidae) with a description of NOR polymorphism in H. nana. J Hered 2003, 94:149-154.

11. Gruber SL, Haddad CFB, Kasahara S: Evaluating the karyotypic diversity in species of Hyla (Anura; Hylidae) with $2 n=30$ chromosomes based on the analysis of ten species. Folia Biol 2005, 51:68-75.

12. Wiens JJ, Kuczynski CA, Hua X, Moen DS: An expanded phylogeny of treefrogs (Hylidae) based on nuclear and mitochondrial sequence data. Mol Phylogenet Evol 2010, 55:871-882.

13. Pyron RA, Wiens JJ: A large-scale phylogeny of Amphibia including over 2800 species, and a revised classification of extant frogs, salamanders, and caecilians. Mol Phylogenet Evol 2011, 61:543-583.

14. Duellman WE: A new species of small yellow Hyla from Peru (Anura: Hylidae). Amphibia-Reptilia 1982, 3:153-160.

15. Fouquet A, Noonan B, Blanc M, Orrico VGD: Phylogenetic position of Dendropsophus gaucheri (Lescure and Marty 2000) highlights the need for an in-depth investigation of the phylogenetic relationships of Dendropsophus (Anura: Hylidae). Zootaxa 2011, 3035:59-67.

16. Napoli MF, Caramaschi U: Duas novas espécies de Hyla Laurenti, 1768 do Brasil central afins de H. tritaeniata Bokermann, 1965 (Amphibia, Anura, Hylidae). Bol Mus Nac 1998, 391:1-12.

17. Napoli MF, Caramaschi U: Geographic variation of Hyla rubicundula and Hyla anataliasiasi with the description of a new species (Anura, Hylidae). Alytes 1999, 16:165-189.

18. Carvalho-e-Silva SP, Carvalho-e-Silva AMPT, Izecksohn E: Nova espécie de Hyla Laurenti do grupo de H. microcephala Cope (Amphibia, Anura, Hylidae) do nordeste do Brasil (Amphibia, Anura, Hylidae). Rev Bras Zool 2003, 20:553-558.

19. Langone JA, Basso NG: Distribucion geografica y sinonima de Hyla nana Boulenger, 1889 y Hyla sanborni Schmidt, 1944 (Anura, Hylidae) y observaciones sobre formas afines. Com Zool Mus Hist Nat Montevideo 1987, 164:1-17.

20. Barrio A: Sobre la validez de Hyla sanborni y D. uruguaya (Anura, Hylidae). Physis 1967, 26:521-524.

21. Cei JM: Additional notes to "Amphibians of Argentine": an update, 19801986. Monitore Zool Ital 1980, 21:209-272. 
22. Basso NG, Perí SI, di Tada IE: Revalidacion de Hyla sanborni, Schmidt, 1944 (Anura: Hylidae). Cuad Herp 1985, 1:1-11.

23. Lutz B: Brazilian species of Hyla. Austin and London: University of Texas Press; 1973.

24. Duellman WE: Liste der rezenten Amphibien und Reptilien: Hylidae, Centrolenidae, Pseudidae. Das Tierreich 1977, 95:1-225.

25. Napoli MF, Caramaschi U: Description and variation of a new Brazilian species of Hyla rubicundula group (Anura, Hylidae). Alytes 2000, 17:165-184.

26. Catroli GF, Kasahara S: Cytogenetic data on species of the family Hylidae (Amphibia, Anura): results and perspectives. Pub/ UEPG Ci Biol Saúde 2009, 15:67-86.

27. Green DM, Sessions SK: Nomenclature for chromosomes. In Amphibian Cytogenetics and Evolution. Edited by Green DM, Sessions SK. San Diego: Academic; 1991:431-432.

28. Wiens JJ, Fetzner JW, Parkinson CL, Reeder TW: Hylid frog phylogeny and sampling strategies for speciose clades. Syst Biol 2005, 54:778-807.

29. Fouquet A, Gilles A, Vences M, Marty C, Blanc M, Gemmell NJ: Underestimation of species richness in Neotropical frogs revealed by mtDNA analyses. PLOS One 2007, 2:e1109. doi:10.1371/journal.pone.0001109.

30. Faivovich J, Garcia PCA, Ananias F, Lanari L, Basso NG, Wheeler WC: A molecular perspective on the phylogeny of the Hyla pulchella species group (Anura, Hylidae). Mol Phylogenet Evol 2004, 32:938-950.

31. Wiens JJ, Graham CH, Moen DS, Smith SA, Reeder TW: Evolutionary and ecological causes of the latitudinal diversity gradient in hylid frogs: treefrog trees unearth the roots of high tropical diversity. Am Nat 2006, 168:579-596.

32. Jungfer $\mathrm{KH}$, Reichle S, Piskurek O: Description of a new cryptic southwestern Amazonian species of leaf-gluing treefrog, genus Dendropsophus (Amphibia: Anura: Hylidae). Salamandra 2010, 46:204-214.

33. Darst CR, Cannatella DC: Novel relationships among hyloid frogs inferred from $12 \mathrm{~S}$ and $16 \mathrm{~S}$ mitochondrial DNA sequences. Mol Phylogenet Evol 2004, 31:462-475.

34. King M, Rofe R: Karyotype variation in the Australian gekko Phyllodactylus marmoratus (Gray) (Gekkonidae: Reptilia). Chromosoma 1976, 54:75-87.

35. Schmid M: Chromosome banding in Amphibia I. Constitutive heterochromatin and nucleolus organizer regions in Bufo and Hyla. Chromosoma 1978, 66:361-388.

36. King M: C-banding studies in Australian hylid frogs: secondary constriction structure and the concept of euchromatin transformation. Chromosoma 1980, 80:191-207.

37. Howell WM, Black DA: Controlled silver staining of nucleolus organizer regions with a protective colloidal developer: a 1-step method. Experientia 1980, 36:1014-1015.

38. Viegas-Péquignot E: In situ hybridization to chromosomes with biotinylated probes. In In Situ Hybridization: a Practical Approach. Edited by Willernson D. Oxford: Oxford University Press; 1992:137-158.

39. Meunier-Rotival M, Cortadas J, Macaya G: Isolation and organization of calf ribosomal DNA. Nucleic Acids Res 1979, 6:2109-2123.

40. Graybeal A: Phylogenetic relationships of bufonid frogs and tests of alternate macroevolutionary hypotheses characterizing their radiation. Zool. Jour. Linn. Soc. 1997, 119:297-338.

41. Varón A, Vinh LS, Wheeler WC: POY version 4: phylogenetic analysis using dynamic homologies. Cladistics 2010, 26:72-85.

42. Goloboff PA, Farris JS, Nixon KC: T.N.T.: Tree analysis using new technology. Program and documentation. 2003 [Available at www.zmuc.dk/public/phylogeny].

43. Ronquist F, Huelsenbeck JP: MrBayes 3: Bayesian phylogenetic inference under mixed models. Bioinformatics 2003, 19:1572-1574.

44. Nylander JAA: MrModeltest v2. Program distributed by the author. Uppsala University: Evolutionary Biology Centre; 2004.

45. Thompson JD, Higgins DG, Gibson TJ: Clustal W: improving the sensitivity of progressive multiple sequence alignment through sequence weighting, position specific gap penalties and weight matrix choice. Nucleic Acids Res 1994, 22:4673-4680.

\section{doi:10.1186/1471-2156-14-59}

Cite this article as: Medeiros et al:: Comparative cytogenetic analysis of some species of the Dendropsophus microcephalus group (Anura, Hylidae) in the light of phylogenetic inferences. BMC Genetics 2013 14:59.

\section{Submit your next manuscript to BioMed Central and take full advantage of:}

- Convenient online submission

- Thorough peer review

- No space constraints or color figure charges

- Immediate publication on acceptance

- Inclusion in PubMed, CAS, Scopus and Google Scholar

- Research which is freely available for redistribution 